\title{
Detection of Epstein-Barr virus in gastric adenocarcinoma: qPCR and FISH comparison
}

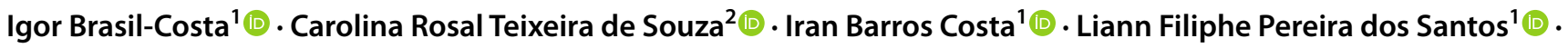

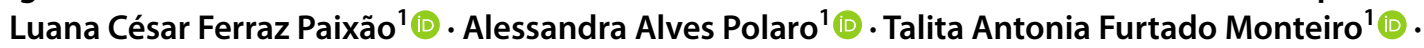 \\ Rommel Mario Rodríguez Burbano ${ }^{2,3}$ (i)
}

Received: 24 March 2021 / Accepted: 18 November 2021 / Published online: 3 December 2021

(c) The Author(s) 2021

\begin{abstract}
EBV-associated gastric cancer accounts for about $10 \%$ of all gastric carcinomas worldwide. We aimed to verify the prevalence of EBV in gastric adenocarcinoma samples using FISH and qPCR and comparing the results obtained by both techniques. Gastric cancer samples from 191 cases were analyzed. The FISH assay was performed to detect small EBV RNAs (EBER1) and qPCR was performed to detect the EBV-EBNA-1 gene region. Cohen's kappa index and the chi-square test were used to compare the methodologies and investigate correlations with the clinical-pathological data of the gastric adenocarcinoma patients. Most of the patients were men, and the average age was 60 years. The intestinal subtype cancer presented more aggressive stages with $90 \%$ of patients having a reactive FISH for EBV $(\mathrm{EBV}+)$, although the virus infection frequency in epithelial gastric tissue was only $1 \%$. No positive association with clinicopathological features and EBV+ was found by FISH. Using qPCR analysis, the percentage of positive samples was lower (52.4\%), and a positive association was found in samples from older patients ( $>60$ years). Interestingly, 71 qPCR-negative cases were detected by FISH in the presence of non-epithelial cells and in 10 qPCR-positive cases with no evidence of EBV according to FISH. The concordance between the two techniques was low, with only $57.6 \%$. FISH is more informative for associating the gastric carcinoma with EBV positivity in tumor/epithelial cells; however, qPCR can provide relevant information regarding the progression and characteristics of neoplasia.
\end{abstract}

Keywords Gastric cancer $\cdot$ Epstein-Barr virus $(\mathrm{EBV}) \cdot \mathrm{qPCR} \cdot$ FISH $\cdot$ Methodological comparison $\cdot$ Brazil

\section{Introduction}

Approximately $20 \%$ of all cancer cases have a virus as an etiological factor [1]. In this context, Epstein-Barr virus (EBV) is associated with several types of malignant neoplasms, including gastric cancer. EBV-associated gastric

Edited by: Thomas F. Schulz.

Carolina Rosal Teixeira de Souza

carolrosal@ufpa.br

1 Virology Section, Evandro Chagas Institute, Ananindeua, Pará 67030-000, Brazil

2 Laboratory of Human Cytogenetics, Institute of Biological Sciences, Federal University of Pará, Belém, Pará 66075-110, Brazil

3 Molecular Biology Laboratory, Ophir Loyola Hospital, Belém, Pará 66060-281, Brazil cancer (EBVaGC) comprises about $10 \%$ of all gastric carcinomas worldwide [1,2], affects more men, and globally ranks number one for deaths associated with the virus. The number of deaths linked to EBVaGC is exponentially proportional to age, primarily after 60 years [3].

EBV can reach the stomach through the saliva as a free virus particle in virus-infected B lymphocytes as well as infected oropharyngeal epithelial cells [4]. As the mucosal cells do not express CD21 (i.e., the classic EBV receptor typically found in B lymphocytes), these infected cells interact with other gastric cells [5]. EBV-positive tumors comprised $9 \%$ of all tumors classified by The Cancer Genome Atlas (TCGA) network [6].

The presence of EBV in a patient with gastric cancer was first described using polymerase chain reaction (PCR) in a case of undifferentiated lymphoepithelioma type gastric cancer, a histological type similar to nasopharyngeal lymphoepithelioma $[7,8]$. The stomach is generally classified 
into two topographical subsites, the cardia (upper stomach) and noncardia (lower stomach) [9]. EBV loses infectivity more readily upon reaching the stomach, which may explain the higher prevalence of gastric cancer associated with the virus in the upper part of the organ [10]. Among all types of gastric cancer, adenocarcinomas account for about $95 \%$ of cases [9], and approximately $10 \%$ of these are associated with EBV [10]. The TNM Classification of Malignant Tumors (TNM) is internationally accepted for classifying this type of gastric cancer into stages I, II, III, and IV, reflecting an increasing order of severity, size, and malignancy $[11,12]$.

Imai et al. [13] analyzed 1,000 cases of gastric carcinomas randomly selected and, through the combined diagnosis of PCR and in situ hybridization (ISH), demonstrated the presence of the virus in 70 cases $(7 \%)$. In a subsequent study, Sousa et al. [14] analyzed more than 30,000 samples of patients with stomach cancer and identified the presence of EBV DNA in $8 \%$ of these.

It is understood that in histological material, the methods of choice for demonstrating the presence of EBV are in situ hybridization (ISH) with labeled nucleic acid probes and the Southern blot test. However, quantitative polymerase chain reaction (qPCR) is still widely used, as it is a more sensitive detection methodology [15].

The aim of this study was to verify the prevalence of EBV in gastric adenocarcinoma samples by means of two methodologies widely used for virus detection in neoplastic samples, in addition to comparing the results with clinicopathologic variables.

\section{Methods}

In the present study, two methods of direct detection of EBV nucleic acids were used: a) fluorescent in situ hybridization (FISH) for the detection of small EBV RNAs (EBER1) and b) quantitative polymerase chain reaction (qPCR) for detection of the EBV-EBNA-1 gene region.

\section{Study population, tumor samples, and clinical data}

Gastric cancer samples were obtained between 1998 and 1999 from Ophir Loyola Hospital, which received patients from all over the state of Pará, Brazil. A total of 356 samples of gastric adenocarcinoma were obtained from paraffin-embedded tissue, and DNA was extracted from fresh tumors. Despite this, only 191 samples had both the DNAPI-paraffined material; thus, they were used to compare the methodologies. Patients were not required to give informed consent to the study because the analysis used anonymous clinical data that were obtained after each patient agreed to treatment by written consent.
The samples were stored in the Laboratory of Human Cytogenetics of the Federal University of Pará (LCH/UFPA) until use. The epidemiological and clinicopathological characteristics of the patients were obtained through the analysis of medical records of the hospital and LCH/UFPA's gastric tumor database. The study was forwarded and approved (opinion number 121.902 of September 27, 2012) by the Research Ethics Committee of the Evandro Chagas Institute in accordance with the norms regulating research involving human beings.

\section{EBV detection}

For the FISH assay, small EBV RNAs (EBER1), which are highly expressed in cells with latent infection, were investigated in slides with approximately $5 \mu \mathrm{m}$ of tissue. For this, the Clark Laboratories ${ }^{\mathrm{TM}}$ Kit was used according to the manufacturer's instructions.

The DNA of formalin-fixed, paraffin-embedded (FFPE) tissues of gastric adenocarcinomas (4-5 slices of $5 \mu \mathrm{m}$ of tissue) was obtained using a QIAamp DNA FFPE Tissue Kit (QIAGEN, Venlo, Netherlands), and DNA from fresh tissue $(200 \mu \mathrm{g})$ was extracted using TRIzol ${ }^{\circledR}$ (Thermo Fisher Scientific, Massachusetts, USA), following the manufacturer's instructions. Then, the DNA was quantified with the Qubit ${ }^{\circledR}$ dsDNA BR Assay kit on Qubit ${ }^{\circledR}$ equipment (Thermo Fisher Scientific, Massachusetts, USA). The qPCR test was performed for the detection of the EBV-EBNA-1 gene region, using the qPCRAlert EBV ${ }^{\circledR}$ Kit (NANOGEM), on the Rotorgene $\mathrm{Q}^{\circledR}$ equipment (QIAGEN, Venlo, Netherlands), with initial programming at $50^{\circ} \mathrm{C}$ for $2 \mathrm{~min}$ for decontamination and $95^{\circ} \mathrm{C}$ for $10 \mathrm{~min}$ for initial denaturation, followed by 45 cycles of $95{ }^{\circ} \mathrm{C}$ for $15 \mathrm{~s}$ for annealing and $60{ }^{\circ} \mathrm{C}$ for a $1 \mathrm{~min}$ extension. A standard curve (with controls with $10^{5}, 10^{4}$, $10^{3}$, and $10^{2}$ copies) was used to verify the efficiency of the reaction, and ultrapure water was used as a negative control.

\section{Statistical analysis}

The Shapiro-Wilk test was used to evaluate the distribution of the samples. The results of the analyses of infection by the two methodologies were correlated with the clinicalpathological data of the gastric adenocarcinoma patients using the Chi-square test. The comparison between methodologies for EBV detection was performed using Cohen's kappa index. Considering ISH as the gold-standard method for EBV detection in tumor tissues, the sensitivity and specificity values were also calculated for PCR. A significance level of $P<0.05$ was used for all analyses, and a 95\% confidence interval was also applied. The results are given as the $P$ value, odds ratio (OR), and confidence interval (CI). The statistical methods were performed on BioEstat v5.3 (https:// www.mamiraua.org.br/downloads/programas/) and were 
reviewed by Carlos Eduardo de Melo Amaral, a biomedical statistician, from the Pará State Center for Hematology and Hemotherapy.

\section{Results}

Of the 191 cases of gastric adenocarcinoma studied, the mean age of the patients at the time of sampling collection was 60 (min.: 28; max.: 89) and the majority were men (135; $70.7 \%)$. Nearly $55 \%(106 / 191)$ of the tumors were of the intestinal type according to Lauren's criteria [16], and the tumors were distributed as follows in the stomach: $37,7 \%$ (72/191) cardia; $2.6 \%$ (5/191) fundus; $4.2 \%$ (8/191) body; $42.4 \%(81 / 191)$ antrum, and $13.1 \%(25 / 191)$ in more than one region, such as the body and antrum.

Regarding TNM classification and tumor staging, a heterogeneous distribution was observed (Table 1). The majority of the cases were aggressive: T3 or T4 $(159 / 191 ; 83.2 \%)$ and had lymphonodal metastasis (N1, N2, or N3) (182/191; 95.3\%), and almost half (45\%) had distant metastasis. The percentage of cases per stage was $2.09 \%(4 / 191), 26.7 \%$ (51/191), 24.08\% (46/191), and 45.03\% (86/191) for stages I, II, III, and IV, respectively.

Of the paraffin-embedded blocks involved in the project, 90\% (171/190) had reactive FISH. However, only two samples showed fluorescent labeling in coat cells/epithelial cells, which characterizes the presence of EBV in the nucleus of adenocarcinoma tumor cells. The others presented labeling in non-epithelial cells, such as lymphocytes. Therefore, in the present study, the virus infection frequency in the epithelial gastric tissue from patients was found to be $1 \%(2 / 191)$ by FISH.

No positive association $(P>0.05)$ was found with $\mathrm{EBV}(+)$ by FISH technique and the variables gender, age, TNM classification, localization, and tumor histology. However, positive cases are more frequently seen in men aged $\geq 60$ years old, in the proximal region of the stomach, in patients with lymph node metastasis, and in more advanced stages.

Using qPCR analysis, the percentage of positive samples found was lower than that found using FISH (52.4\%; 110/191). The direct association of the qPCR results and the clinical-pathology variables studied by the chi-square test was only statistically significant for the age variable $(P=0.041, \mathrm{OR}=1.829, \mathrm{CI} 1.023-3.267)$, and the virus was more frequently detected in carcinoma biopsies of older patients (Table 2) (mean of 62.25 vs. 57.45 for cases with undetectable virus result).

The presence of metastases was not directly associated with infection. It was also observed that the number of positive $\mathrm{qPCR}$ cases was higher among patients with more
Table 1 TNM classification and staging of gastric adenocarcinoma cases studied

\begin{tabular}{|c|c|c|c|}
\hline Staging & TNM & $\begin{array}{l}\text { Number of } \\
\text { cases }\end{array}$ & Percentage $(\%)$ \\
\hline \multirow[t]{3}{*}{ I } & T1N1M0 & 2 & 1.05 \\
\hline & T2N0M0 & 2 & 1.05 \\
\hline & Subtotal & 4 & 2.09 \\
\hline \multirow[t]{5}{*}{ II } & T2N1M0 & 2 & 1.05 \\
\hline & $\mathrm{T} 2 \mathrm{~N} 2 \mathrm{M} 0$ & 4 & 2.09 \\
\hline & T3N0M0 & 3 & 1.57 \\
\hline & T3N1M0 & 42 & 21.99 \\
\hline & Subtotal & 51 & 26.70 \\
\hline \multirow[t]{7}{*}{ III } & $\mathrm{T} 2 \mathrm{~N} 3 \mathrm{M} 0$ & 3 & 1.57 \\
\hline & T3N2M0 & 25 & 13.09 \\
\hline & T3N3M0 & 1 & 0.52 \\
\hline & T4N1M0 & 5 & 2.62 \\
\hline & T4N2M0 & 10 & 5.24 \\
\hline & T4N3M0 & 2 & 1.05 \\
\hline & Subtotal & 46 & 24.08 \\
\hline \multirow[t]{12}{*}{ IV } & T1N1M1 & 3 & 1.57 \\
\hline & T2N1M1 & 6 & 3.14 \\
\hline & $\mathrm{T} 2 \mathrm{~N} 2 \mathrm{M} 1$ & 8 & 4.19 \\
\hline & $\mathrm{T} 2 \mathrm{~N} 3 \mathrm{M} 1$ & 2 & 1.05 \\
\hline & T3N0M1 & 3 & 1.57 \\
\hline & T3N1M1 & 7 & 3.66 \\
\hline & T3N2M1 & 29 & 15.18 \\
\hline & T3N3M1 & 4 & 2.09 \\
\hline & T4N1M1 & 10 & 5.24 \\
\hline & T4N2M1 & 11 & 5.76 \\
\hline & T4N3M1 & 3 & 1.57 \\
\hline & Subtotal & 86 & 45.03 \\
\hline \multirow[t]{5}{*}{ Undefined } & T3N0Mx & 1 & 0.52 \\
\hline & T3N1Mx & 1 & 0.52 \\
\hline & $\mathrm{T} 3 \mathrm{~N} 2 \mathrm{Mx}$ & 1 & 0.52 \\
\hline & T4N1Mx & 1 & 0.52 \\
\hline & Subtotal & 4 & 2.09 \\
\hline Total & & 191 & 100.00 \\
\hline
\end{tabular}

severe staging (III and IV) $(P>0.05)$. The positivity for EBV in these more severe cancer cases was $73.4 \%$ (80/109).

Interestingly, we found 71 PCR-negative cases with the presence of infected non-epithelial cells detected by ISH, and 10 PCR-positive cases with no evidence of EBV by FISH. The comparison of the two methodologies (FISH and qPCR) applied for the detection of EBV showed that they did not produce similar results (Table 3). Quantitative analyzes of viral genomic equivalent/extraction were performed and correlated with FISH results (including FISH labeling intensity) as well as age, sex, tumor histologic type, and location, but no significant associations were found (Fig. 1). The concordance between the two techniques was $57.6 \%$ 
Table 2 Comparison of EBV positivity by qPCR with clinical-epidemiological variables

\begin{tabular}{lclc}
\hline $\begin{array}{l}\text { Clinical-epidemio- } \\
\text { logical variables }\end{array}$ & EBV positive & EBV Undetectable & $P$ value \\
\hline Age & & & \\
$\geq 60$ years & $64(33.5)$ & $35(18.3)$ & $\mathbf{0 . 0 4 1}$ \\
$<60$ years & $46(24.1)$ & $46(24.1)$ & \\
Gender & & & \\
Male & $75(39.3)$ & $60(31.4)$ & 0.377 \\
Female & $35(18.3)$ & $21(11)$ & \\
Location & & & 0.286 \\
Proximal & $45(23.6)$ & $27(14.1)$ & \\
Distal & $65(34)$ & $54(28.3)$ & 0.137 \\
Histological type & & & \\
Intestinal & $56(29.3)$ & $50(26.2)$ & \\
Diffuse & $54(28.3)$ & $31(16.2)$ & \\
Tumor aggressiveness & & & \\
T1 and T2 & $18(9.4)$ & $14(7.3)$ & 0.866 \\
T3 and T4 & $92(48.2)$ & $67(35.1)$ & \\
Lymph node metastasis & & \\
N0 & $3(1.6)$ & $6(3.1)$ & \\
N1, N2 and N3 & $107(56)$ & $75(39.3)$ & \\
Distant metastasis & $57(30.5)$ & $44(23.5)$ & \\
M0 & $51(27.3)$ & $35(18.7)$ & \\
M1 & & & \\
\hline
\end{tabular}

Bold value indicates significant $P$ value

Table 3 Comparison between the results of the methodologies used to identify the EBV

\begin{tabular}{lll}
\hline & \multicolumn{2}{l}{$\begin{array}{l}\text { In situ hybridization } \\
\text { (epithelial cells) }\end{array}$} \\
\cline { 2 - 3 } qPCR & EBV (+) & EBV (-) \\
\hline EBV (+) & 2 & 108 \\
EBV (-) & 0 & 81 \\
Total & 2 & 189 \\
\hline
\end{tabular}

(Cohen's kappa index $=0.036 ; P>0.05$ ) [17]. In addition, the qPCR test had $58.5 \%$ sensitivity and specificity of $50 \%$, which were considered low.

\section{Discussion}

It is well established that EBV has an important role as a conditioning agent for the appearance and evolution of gastric adenocarcinoma. The presence of the virus may deregulate the expression of several human genes related to the neoplastic process, especially those involved in the immune response $[18,19]$.

Regarding the pathological clinical features, both FISH and qPCR found more EBV in older men and in patients in a more advanced stage of cancer, reproducing the findings obtained by many authors around the world [4, 20, 21]. In addition, the distal region and intestinal type were the most affected. These results corroborate those of Souza et al. [21], who used a sample from the same state (Pará, Brazil) as the one used in this study. Nevertheless, the cases in which epithelial cells were shown to be infected by EBV using FISH belonged to the cardiac region, one was intestinal, and the other was a diffuse adenocarcinoma subtype. This finding agrees with other studies that point to the cardia and corpus as the gastric regions more associated with $\mathrm{EBV}(+)$ in ISH cases [5, 22, 23].

Some meta-analyses found a global prevalence of EBV ranging from 7.96 to $11.3 \%$ on average in patients with gastric cancer [10, 14, 24]. However, the frequency of EBVpositive gastric carcinoma varies widely worldwide, with the lowest prevalence in Europe and highest in America [14].

Considering only epithelial cell staining, the detection rate found by the FISH methodology in the present study was low (1.05\%) compared to most EBV detection studies. Despite this, other studies showed frequencies in line with the results obtained-1.7\% in the United Kingdom [25], 0\% in England [26], and 1.3\% in New Guinea [27].

In Brazil, studies using ISH observed frequencies that varied between 5\% and $11.32 \%$, with the highest percentage obtained in populations of the state of São Paulo [23, 28-31]. For the state of Pará, a percentage of EBV positivity for ISH of $9.6 \%$ was described [21].

In addition to the possible small technical variations, this large variation in the prevalence translates the differentiated condition of each population in relation to the susceptibility to EBVaGC and reinforces the multifactorial nature of this cancer. Although, apparently, this is not influenced by economic factors as there is a high variability within the same country and region.

Using the qPCR molecular tool, a detection rate of 52.4\% (110/191) of EBV was found. Other studies have observed higher percentages, such as Ryan et al. [32], which detected $76.1 \%$ in North and Central America and Nogueira et al. [25], which observed $90.2 \%$ in Portugal using the qPCR methodology, and Aquino et al. [33], which found a prevalence of $80 \%$ in Manaus (city of the North of Brazil) using conventional PCR. However, contrasting results were verified by Martínez-López et al. [34] in Mexico and Lee et al. [35] in South Korea, with percentages of $10.67 \%$ and $10 \%$, respectively, using conventional PCR. The large variation in the percentage values of virus detection by molecular biology can be attributed to the different sensitivities of the PCR or qPCR used in each study.

It is important to report that the PCR and qPCR methodologies identify the genetic material of the virus present in the DNA of the sample present in the tumor stroma, regardless of which cell the DNA belongs to (e.g., tumoral 
(A)

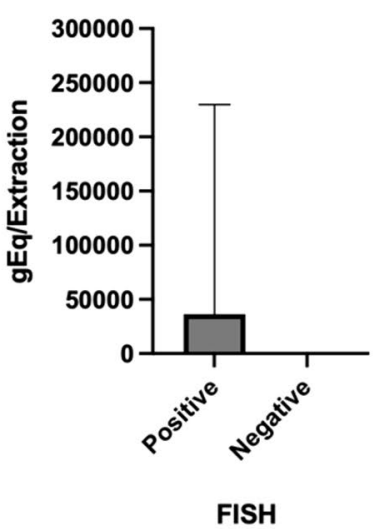

(D)

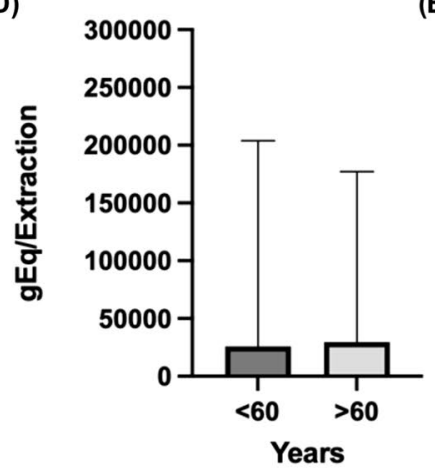

(B)

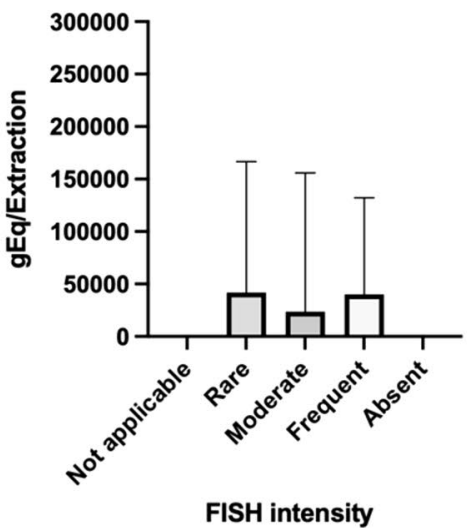

(E)

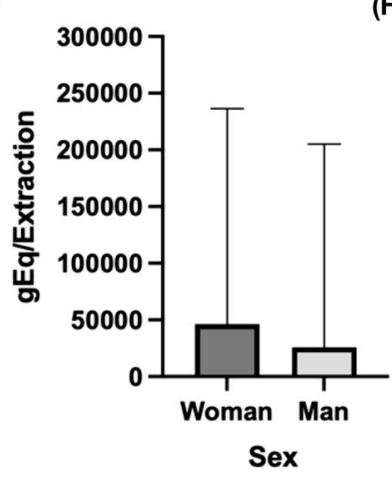

(C)

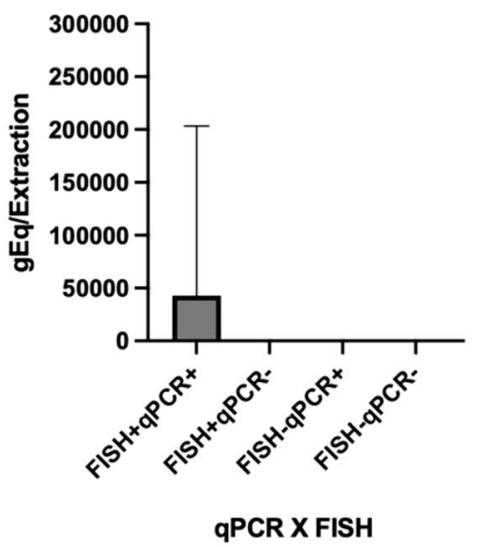

(F)

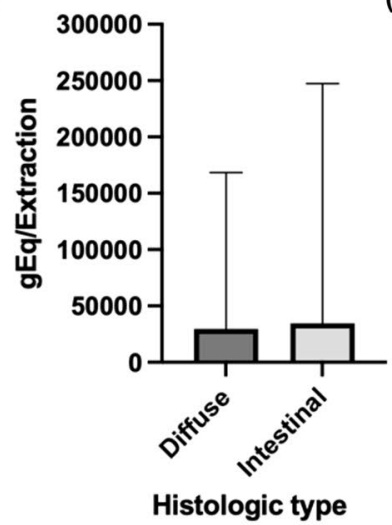

(G)

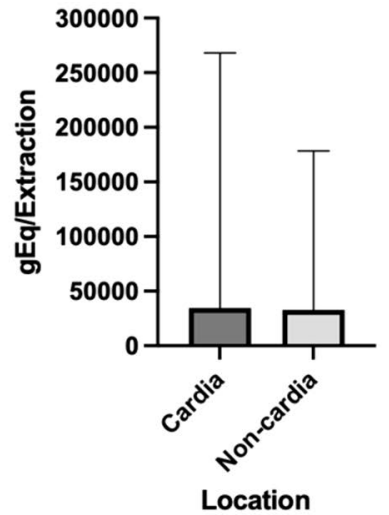

Fig. 1 Distribution of viral load detected by qPCR and its relationship with FISH (A), FISH signal intensity (B) groups comparison (C), age (D), sex $(\mathbf{E})$, tumor histologic type $(\mathbf{F})$, and tumor location $(\mathbf{G})$

or B lymphocytes) [22]. Additionally, the qPCR(+) results with FISH(-) staining in any cell can occur because the qPCR detects a small number of infiltrating EBV-positive lymphocytes that may not be detected by FISH since the amount of tissue used to extract DNA for qPCR is greater than the sections used for FISH. To minimize this difference, we also tried to correlate the viral genomic equivalent quantity/extraction (Fig. 1); however, no association was found. Other works have been successful in demonstrating the association between EBV viral load and disease severity [36, 37].

The greater the number of circulating EBV-infected B lymphocytes, the easier it is to find access to gastric tissue and, consequently, the easier it is for it to be detected by molecular biology methods, such as qPCR, in tumor tissue [38]. At the cellular level, patients with gastric cancer have decreased numbers of $\mathrm{CD} 3+$ and CD8+ cells and an increase in CD4+, CD19+, CD44+, CD25+, and NK compared to a disease-free control [39]. The greater proliferation of CD19+ cells increases the chances of reactivation of EBV since it is the cell for which the virus has a higher affinity
[40]. According to the clonal proliferation of these cells, viral load may be more representative.

In the present study, the comparison of the results obtained from FISH and qPCR showed fair concordance (Cohen's kappa index =0.036) [17]. In addition, the qPCR test had $58.5 \%$ sensitivity and specificity of $50 \%$, which are considered low. The difference between the results of the two methodologies is mainly due to the existence of other infected cells such as lymphocytes in the stroma. The fact that some cases were positive using one technique but negative using another-especially those shown as negative cases by FISH but positive by qPCR — may be due to the use of a small and thin slice of tumor tissue for FISH analysis and a greater amount of tumor material for the extraction of genetic material for qPCR. This could have increased the quantity of cells analyzed and potentially infected. Still, Ryan et al. [32] identified a few polymorphisms in the EBV genome, which leads to difficulties in PCR amplification of some viral genes in a few cases, which could explain the $\mathrm{qPCR}(-)$ cases with FISH(+). However, the outcome of FISH is more informative in associating gastric carcinoma with the presence of EBV in tumor/epithelial cells [41, 42]; 
nevertheless, qPCR can provide relevant information regarding the progression and characteristics of the neoplasia.

The definition of the best technique for identifying EBV in gastric cancer is important since EBVaGC has a distinct tumorigenic profile. In addition, it presents the opportunity for using EBV as a potential biomarker for treatment.

\section{Conclusion}

FISH was more informative for associating gastric carcinoma with EBV positivity in tumor/epithelial cells. Additionally, the results suggest that a greater number of cuts or more automated methodologies such as flow cytometry may be used. New research should be encouraged to uncover the role of infected B lymphocytes in gastric carcinogenesis.

Core tip The presence of Epstein-Barr virus (EBV) was investigated by two different methodologies, qPCR and FISH, in gastric adenocarcinomas, and their relationship with the clinicopathological characteristics of these patients. The agreement between the two methodologies was low. FISH was more informative for associating gastric carcinoma with the presence of EBV in tumor/epithelial cells, although qPCR can demonstrate the presence of EBV even before it enters a latent state. The only positive association found was with older patients and qPCR + cases.

Author contributions IB-C carried out the studies, collected the data, performed the laboratory tests and statistical, and drafted the manuscript; CRTS performed the statistical analysis, wrote and reviewed the manuscript; IBC, LFPS, LCFP, and AAP performed the laboratory tests; TAFM review and adjust ISH methodology and provided administrative support; RMRB designed the research and supervised the report.

Funding Scientific initiation scholarships were paid by National Council for Scientific and Technological Development (CNPq). Salaries were paid by Evandro Chagas Institute (IEC) and Federal University of Pará. Equipment and supplies were provided by the IEC. Supported by Evandro Chagas Institute, Secretariat of Health Surveillance, Ministry of Health of Brazil.

\section{Declarations}

Conflict of interest The authors have no conflicts of interest to declare. All co-authors have seen and agree with the contents of the manuscript and there is no financial interest to report.

Availability of data and material Not applicable.

Code availability Not applicable.

Ethics approval Institutional review board statement: This study was reviewed and approved by the Research Ethics Committee of the Evan- dro Chagas Institute in accordance with the norms regulating research involving human beings (opinion number 121.902 of September 27, 2012).

Informed consent Patients were not required to give informed consent to the study because the analysis used anonymous clinical data that were obtained after each patient agreed to treatment by written consent.

Consent for publication Not applicable.

Open Access This article is licensed under a Creative Commons Attribution 4.0 International License, which permits use, sharing, adaptation, distribution and reproduction in any medium or format, as long as you give appropriate credit to the original author(s) and the source, provide a link to the Creative Commons licence, and indicate if changes were made. The images or other third party material in this article are included in the article's Creative Commons licence, unless indicated otherwise in a credit line to the material. If material is not included in the article's Creative Commons licence and your intended use is not permitted by statutory regulation or exceeds the permitted use, you will need to obtain permission directly from the copyright holder. To view a copy of this licence, visit http://creativecommons.org/licenses/by/4.0/.

\section{References}

1. Akram N, Imran M, Noreen M, Ahmed F, Atif M, Fatima Z, Bilal Waqar A (2017) Oncogenic role of tumor viruses in humans. Viral Immunol 30(1):20-27. https://doi.org/10.1089/vim.2016.0109

2. Shibata D, Weiss LM (1992) Epstein-Barr virus-associated gastric adenocarcinoma. Am J Pathol 140:769-774

3. Khan G, Hashim MJ (2014) Global burden of deaths from Epstein-Barr virus attributable malignancies 1990-2010. Infect Agent Cancer 9:38. https://doi.org/10.1186/1750-9378-9-38]

4. Ishii H, Gobe G, Kawakubo Y, Sato Y, Ebihara Y (2001) Interrelationship between Epstein-Barr virus infection in gastric carcinomas and the expression of apoptosis-associated proteins. Histopathology 38:111-119. https://doi.org/10.1046/j.1365-2559.2001. 01037. $\mathrm{x}$

5. Osato T, Imai S (1996) Epstein-Barr virus and gastric carcinoma. Semin Cancer Biol 7:175-182. https://doi.org/10.1006/scbi.1996. 0024

6. Zhang W (2014) TCGA divides gastric cancer into four molecular subtypes: implications for individualized therapeutics. Chin $\mathbf{J}$ Cancer 33(10):469-470. https://doi.org/10.5732/cjc.014.10117

7. Burke AP, Yen TS, Shekitka KM, Sobin LH (1990) Lymphoepithelial carcinoma of the stomach with Epstein-Barr virus demonstrated by polymerase chain reaction. Mod Pathol Off J US Can Acad Pathol 3:377-380

8. Niedobitek G, Herbst H, Young LS, Rowe M, Dienemann D, Germer C, Stein H (1992) Epstein-Barr virus and carcinomas. Expression of the viral genome in an undifferentiated gastric carcinoma. Diagn Mol Pathol 1:103-108

9. Sung H, Ferlay J, Siegel RL, Laversanne M, Soerjomataram I, Jemal A, Bray F (2021) Global cancer statistics 2020: GLOBOCAN estimates of incidence and mortality worldwide for 36 cancers in 185 countries. CA Cancer J Clin. https://doi.org/10.3322/ caac. 21660

10. Takano Y, Kato Y, Sugano H (1994) Epstein-Barr-virus-associated medullary carcinomas with lymphoid infiltration of the stomach. J Cancer Res Clin Oncol 120:303-308. https://doi.org/10.1007/ bf01236388 
11. Edge S, Byrd D, Compton C, Fritz A, Greene F, Trotti A (2010) AJCC cancer staging manual. American Joint Committee on cancer. 7th edition. Chicago

12. Sobin L, Wittekind C (2002) TNM classification of malignant tumours, 6th edition. In: LH Sobin, C. Wittekind. John Wiley \& Sons, INC.

13. Imai S, Koizumi S, Sugiura M, Tokunaga M, Uemura Y, Yamamoto N (1994) Gastric carcinoma: monoclonal epithelial malignant cells expressing Epstein-Barr virus latent infection protein. Sci USA 91:9131-9135. https://doi.org/10.1073/pnas.91.19.9131]

14. Sousa H, Pinto-Correia AL, Medeiros R, Dinis-Ribeiro M (2008) Epstein-Barr virus is associated with gastric carcinoma: the question is what is the significance? World J Gastroenterol 14:43474351. https://doi.org/10.3748/wjg.14.4347]

15. Niller H, Bauer G (2017) Epstein-Barr virus: clinical diagnostics. In: Minarovits J., Niller H (eds.) Humana Press, New York, pp 33-55

16. Lauren $P$ (1965) The two histological main types of gastric carcinoma: diffuse and so-called intestinal-type carcinoma. An attempt at a histo-clinical classification. Acta Pathol Microbiol Scand 64:31-49

17. Landis JR, Koch GG (1977) The measurement of observer agreement for categorical data. Biometrics 33:159-174

18. Naseem M, Barzi A, Brezden-Masley C, Puccini A, Berger MD, Tokunaga R, Battaglin F, Soni S, McSkane M, Zhang W, Lenz HJ (2018) Outlooks on Epstein-Barr virus associated gastric cancer. Cancer Treat Rev 66:15-22. https://doi.org/10.1016/j.ctrv.2018. 03.006

19. Kim SY, Park C, Kim HJ, Park J, Hwang J, Kim JI, Choi MG, Kim S, Kim KM, Kang MS (2015) Deregulation of immune response genes in patients with Epstein-Barr virus-associated gastric cancer and outcomes. Gastroenterology 148:137-147.e9. https://doi.org/ 10.1053/j.gastro.2014.09.020

20. Lima MAP, Ferreira MVP, Barros MAP, de Pardini MI, MC, Ferrasi AC, Rabenhorst SHB, (2012) Epstein-Barr virus-associated gastric carcinoma in Brazil: comparison between in situ hybridization and polymerase chain reaction detection. Braz J Microbiol 43:393-404. https://doi.org/10.1590/S1517-838220120001000 048

21. Souza CRT, de Oliveira KS, Ferraz JJS, Leal MF, Calcagno DQ, Seabra AD, Khayat AS, Montenegro RC, Alves APNN, Assumpção PP, Smith MC, Burbano RR (2014) Occurrence of Helicobacter pylori and Epstein-Barr virus infection in endoscopic and gastric cancer patients from Northern Brazil. BMC Gastroenterol 14:179. https://doi.org/10.1186/1471-230X-14-179

22. Trimeche M, Ksiaa F, Ziadi S, Mestiri S, Hachana M, Ben GR, Sriha B, Korbi S (2009) Prevalence and characteristics of EpsteinBarr virus-associated gastric carcinomas in Tunisia. Eur J Gastroenterol Hepatol 21:1001-1007. https://doi.org/10.1097/MEG. Ob013e32831f1f53

23. Koriyama C, Akiba S, Iriya K, Yamaguti T, Hamada GS, Itoh T, Eizuru Y, Aikou T, Watanabe S, Tsugane S, Tokunaga M (2001) Epstein-Barr virus-associated gastric carcinoma in Japanese Brazilians and non-Japanese Brazilians in Sao Paulo. Jpn J Cancer Res 92:911-917. https://doi.org/10.1111/j.1349-7006.2001.tb011 80.x

24. Tavakoli A, Monavari SH, Solaymani Mohammadi F, Kiani SJ, Armat S, Farahmand M (2020) Association between EpsteinBarr virus infection and gastric cancer: a systematic review and meta-analysis. BMC Cancer 20(1):493. https://doi.org/10.1186/ s12885-020-07013-x

25. Burgess DE, Woodman CB, Flavell KJ, Rowlands DC, Crocker J, Scott K, Biddulph JP, Young LS, Murray PG (2002) Low prevalence of Epstein-Barr virus in incident gastric adenocarcinomas from the United Kingdom. Br J Cancer 86:702-704. https://doi. org/10.1038/sj.bjc.6600107
26. Shousha S, Luqmani YA (1994) Epstein-Barr virus in gastric carcinoma and adjacent normal gastric and duodenal mucosa. J Clin Pathol 47:695-698. https://doi.org/10.1136/jcp.47.8.695

27. Morewaya J, Koriyama C, Akiba S, Shan D, Itoh T, Eizuru Y (2004) Epstein-Barr virus-associated gastric carcinoma in Papua New Guinea. Oncol Rep 12:1093-1098. https://doi.org/10.3892/ or.12.5.1093

28. Hayashi K, Chen WG, Chen YY, Murakami I, Chen HL, Ohara N, Nose S, Hamaya K, Matsui S, Bacchi MM, Bacchi CE, Chang KL, Weiss LM (1998) Deletion of Epstein-Barr virus latent membrane protein 1 gene in Japanese and Brazilian gastric carcinomas, metastatic lesions, and reactive lymphocytes. Am J Pathol 152:191-198

29. Lopes LF, Bacchi MM, Elgui-de-Oliveira D, Zanati SG, Alvarenga M, Bacchi CE (2004) Epstein-Barr virus infection and gastric carcinoma in Sao Paulo State, Brazil. Braz J Med Biol Res 37:1707-1712. https://doi.org/10.1590/s0100-879x20040011000 16

30. Lima VP, de Lima MAP, Andre AR, Ferreira MVP, Barros MAP, Rabenhorst SHB (2008) H pylori (CagA) and Epstein-Barr virus infection in gastric carcinomas: correlation with p53 mutation and c-Myc, Bcl-2 and Bax expression. World J Gastroenterol 14:884-891. https://doi.org/10.3748/wjg.14.884

31. Pereira MA, Ramos MFKP, Faraj SF, Dias AR, Yagi OK, Zilberstein B, Cecconello I, Alves VAF, de Mello ES, Ribeiro U Jr (2018) Clinicopathological and prognostic features of EpsteinBarr virus infection, microsatellite instability, and PD-L1 expression in gastric cancer. J Surg Oncol 117(5):829-839. https://doi. org/10.1002/jso.25022

32. Ryan JL, Morgan DR, Dominguez RL, Thorne LB, Elmore SH, Mino-Kenudson M, Lauwers GY, Booker JK, Gulley ML (2009) High levels of Epstein-Barr virus DNA in latently infected gastric adenocarcinoma. Lab Invest 89:80-90. https://doi.org/10.1038/ labinvest.2008.103

33. de Aquino PF, Carvalho PC, da Gama Fischer JS, de Souza AQL, Viana JS, Chalub SRS, de Souza ADL, Carvalho MGC (2012) Epstein-Barr virus DNA associated with gastric adenocarcinoma and adjacent non-cancerous mucosa in patients from Manaus, Brazil. Genet Mol Res 11:4442-4446. https://doi.org/10.4238/2012. October.15.3

34. Martinez-Lopez JLE, Torres J, Camorlinga-Ponce M, Mantilla A, Leal YA, Fuentes-Panana EM (2014) Evidence of Epstein-Barr virus association with gastric cancer and non-atrophic gastritis. Viruses 6:301-318. https://doi.org/10.3390/v6010301

35. Lee MA, Hong YS, Kang JH, Lee KS, You JY, Lee KY, Park CH (2004) Detection of Epstein-Barr virus by PCR and expression of LMP1, p53, CD44 in gastric cancer. Korean J Intern Med 19:43-47. https://doi.org/10.3904/kjim.2004.19.1.43

36. Ayee R, Ofori MEO, Tagoe EA, Languon S, Searyoh K, Armooh L, Bilson-Amoah E, Baidoo K, Kitcher E, Wright E, Quaye O (2020) Genotypic characterization of Epstein Barr virus in blood of patients with suspected nasopharyngeal carcinoma in ghana. Viruses 12(7):766. https://doi.org/10.3390/v12070766

37. Cao P, Zhang M, Wang W, Dai Y, Sai B, Sun J, Wang L, Wang F, Li G, Xiang J (2017) Fluorescence in situ hybridization is superior for monitoring Epstein Barr viral load in infectious mononucleosis patients. BMC Infect Dis 17(1):323. https://doi.org/10.1186/ s12879-017-2412-y (PMID:28468603;PMCID:PMC5415799)

38. Oda K, Koda K, Takiguchi N, Nunomura M, Seike K, Miyazaki M (2003) Detection of Epstein-Barr virus in gastric carcinoma cells and surrounding lymphocytes. Gastric Cancer 6:173-178. https://doi.org/10.1007/s10120-003-0247-2

39. Yu QM, Yu CD, Ling ZQ (2012) Elevated circulating CD19+ lymphocytes predict survival advantage in patients with gastric cancer. Asian Pac J Cancer Prev 13:2219-2224. https://doi.org/ 10.7314/apjcp.2012.13.5.2219 
40. Borza CM, Hutt-Fletcher LM (2002) Alternate replication in B cells and epithelial cells switches tropism of Epstein-Barr virus. Nat Med 8:594-599. https://doi.org/10.1038/nm0602-594

41. Qi ZL, Han XQ, Hu J, Wang GH, Gao JW, Wang X, Liang DY (2013) Comparison of three methods for the detection of EpsteinBarr virus in Hodgkin's lymphoma in paraffin-embedded tissues. Mol Med Rep 7:89-92. https://doi.org/10.3892/mmr.2012.1163
42. Chen XZ, Chen H, Castro FA, Hu JK, Brenner H (2015) EpsteinBarr virus infection and gastric cancer: a systematic review. Medicine (Baltimore) 94:e792. https://doi.org/10.1097/MD.00000 00000000792

Publisher's Note Springer Nature remains neutral with regard to jurisdictional claims in published maps and institutional affiliations. 